\title{
Production of Lettuce Seedlings with Association of Diazotrophic Bacteria and Humic Acids
}

\author{
Carlos Augusto Rocha de Moraes Rego ${ }^{*}$, Bruna Penha Costa1, Marinez Carpiski Sampaio1, \\ Marcos Massuo Kashiwaqui' ${ }^{1}$, João Henrique Silva Caetano', Vandeir Francisco Guimarães' \\ Juan López de Herrera ${ }^{2}$, Pablo Wenderson Ribeiro Coutinho ${ }^{1}$, Cláudio Yuji Tsutsumi ${ }^{1}$, \\ Maria Soraia Fortado Vera Cruz' ${ }^{1}$, Thatiane Nepomuceno Alves' ${ }^{1}$, Shirlene Souza Oliveira1, \\ Ana Carolina Pinguelli Ristau1, Hannah Braz'1
}

${ }^{1}$ Center of Agrarian Sciences, State University of Western Paraná, Marechal Cândido Rondon, Brazil

${ }^{2}$ University School of Agricultural Technical Engineering, Polytechnic University of Madrid, Madrid, Spain

Email: *cassielcarlos@hotmail.com

How to cite this paper: de Moraes Rego, C.A.R., Costa, B.P., Sampaio, M.C., Kashiwaqui, M.M., Caetano, J.H.S., Guimarães, V.F., de Herrera, J.L., Coutinho, P.W.R., Tsutsumi, C.Y., Cruz, M.S.F.V., Alves, T.N., Oliveira, S.S., Ristau, A.C.P. and Braz, H. (2018) Production of Lettuce Seedlings with Association of Diazotrophic Bacteria and Humic Acids. American Journal of Plant Sciences, 9, 946-957. https://doi.org/10.4236/ajps.2018.95072

Received: March 3, 2018

Accepted: April 15, 2018

Published: April 18, 2018

Copyright $\odot 2018$ by authors and Scientific Research Publishing Inc. This work is licensed under the Creative Commons Attribution International License (CC BY 4.0).

http://creativecommons.org/licenses/by/4.0/ (c) (i) Open Access

\begin{abstract}
The objective of this work was to verify the responses in agronomic and physiological characters of lettuce seedlings when submitted to different doses of humic acids and the presence or absence of inoculation of the bacterium Azospirillum brasilense. The experiment was carried out at the Protected Cultivation Station and Biological Control Teacher Mário César Lopes, belonging to the Experimental Stations Nucleus of the State University of the West of Paraná. The experimental design was a randomized block design, in a $5 \times 2$ factorial scheme, with four repetitions, totaling 40 plots. The first factor consisted of five solutions containing humic acid (100\%, 75\%, 50\%, 25\% and $0 \%)$ and the second factor was the presence or absence of the diazotrophic bacterium Azospirillum brasilense obtained by commercial product. Germination tests were carried out in addition to the determination of agronomic characters such as the number of fully expanded leaves, plant height, stem diameter, main root length, shoot dry mass, root dry mass, total dry mass, and Dickson quality index. The association of diazotrophic bacteria and humic acids did not influence the emergency rate, mean emergence time, mean speed of emergency, emergence speed index, plant height, and root length of lettuce seedlings. The dilutions of humic acids, regardless of inoculation with bacteria diazotrophic favored the development of the number of leaves, stem diameter and Dickson quality index. Inoculation of lettuce seeds with diazotrophic bacteria associated with the addition of humic acids, favored the development of the dry mass of root and total dry matter.
\end{abstract}




\section{Keywords}

Azospirillum brasilense, Humic Substances, Lactuca sativa L., Productive Characteristics

\section{Introduction}

The lettuce (Lactuca sativa L.) is one of the most important leafy vegetables in Brazil, belonging to the Asteraceae family, being cultivated and consumed throughout the country [1]. As a result, the production of quality seedlings is a determining factor for the success of any enterprise related to cultivation.

The production of seedlings is a technique used by the producer to reduce the harvest time, thus increasing the number of productive cycles per year, consequently allowing better utilization of the area and greater financial return [2]. However, malformation of seedlings reduces the initial growth of plants in the field, affecting the crop yield and limiting the genetic potential of cultivars [3].

Some techniques favor the production of quality seedlings, such as water availability with good quality, cultivation in appropriate places or in greenhouses, use of substrates and containers for this purpose. In addition, other ecological and economic alternatives can be adopted for the quality of seedlings, such as the use of humic substances and growth promoting bacteria [4]. The use of growth promoting and nitrogen fixing bacteria that may benefit the initial development of plants by several factors, such as nitrogen fixation, root development improvement among others are good techniques for lettuce culture [5].

Some researchers have demonstrated the influence of humic acids on plants, such as the promotion of rooting [6], the growth and development of root and aerial structures, as well as crop productivity and quality [1], with potential gain in economic income for the producer [4]. Its use as a biostimulant can attenuate the effect of potentially toxic substances, promoting improvements in the physical and biological conditions of the medium, improving the absorption of nutrients, and inducing changes in several metabolic processes, such as in the proton pump activity affecting the potential of membranes, on glycolysis and Krebs cycle, the release of molecules with hormonal activities, such as auxin, cytokinin, gibberellin and polyamines [7] [8].

The increase in crop production can be optimized through the use of a biofertilizer with prokaryotic microorganisms, capable of fixing atmospheric nitrogen in the soil and make it available to plants [9]. The mixture of humic substances associated with growth promoting bacteria shows positive results in the development of various crops such as corn [7], wheat [10], tomato [11] and lettuce [4].

However, the success in the combined use of these compounds is dependent on several factors, such as the crop in which the substance is used, the dilution applied and the origin of the humic substances used [11] [12]. Therefore, studies 
focusing on the definition of humic acid doses in lettuce cultivation are important tools for the successful application of these substances combined with growth promoting bacteria.

The objective of this study was to verify the responses in agronomic and physiological characters of lettuce seedlings when they are submitted to different doses of humic acids and the presence or absence of inoculation of the bacterium Azospirillum brasilense.

\section{Material and Methods}

The experiment was carried out at the Protected Cultivation Station and Biological Control Teacher Mário César Lopes, belonging to the Experimental Station Nucleus of the State University of the West of Paraná (UNIOESTE), University campus of Marechal Cândido Rondon, Paraná. The location coordinates are latitude $24^{\circ} 33^{\prime} 29.44^{\prime \prime S}$ and longitude $54^{\circ} 02^{\prime} 43.37^{\prime \prime} \mathrm{W}$ and with an altitude of 411 meters, in relation to sea level. According to the classification of Köppen the climate of the region is mesothermal type Cfa humid subtropical of dry winter, with rains well distributed throughout the year and hot summers [13]. The annual mean temperature is between 295.15 to $296.15 \mathrm{~K}$ and the mean annual precipitation total of 1600 to 1800 millimeters [14]. Regarding the temperature inside the greenhouse during the experiment period are presented in Figure 1.

The experimental design was a randomized block design, in a $5 \times 2$ factorial scheme, with four replications, totaling 40 plots and being evaluated the results of the separated factors and the interaction between them. The first factor consisted of five solutions containing humic acid (100\%, 75\%, 50\%, 25\% and $0 \%)$, the dilutions were obtained by proportionally using the content in milliliters of humic acid with distilled water, extracted from an oxisol cultivated oat and handled in livestock farming systems integration, obtained through the differential

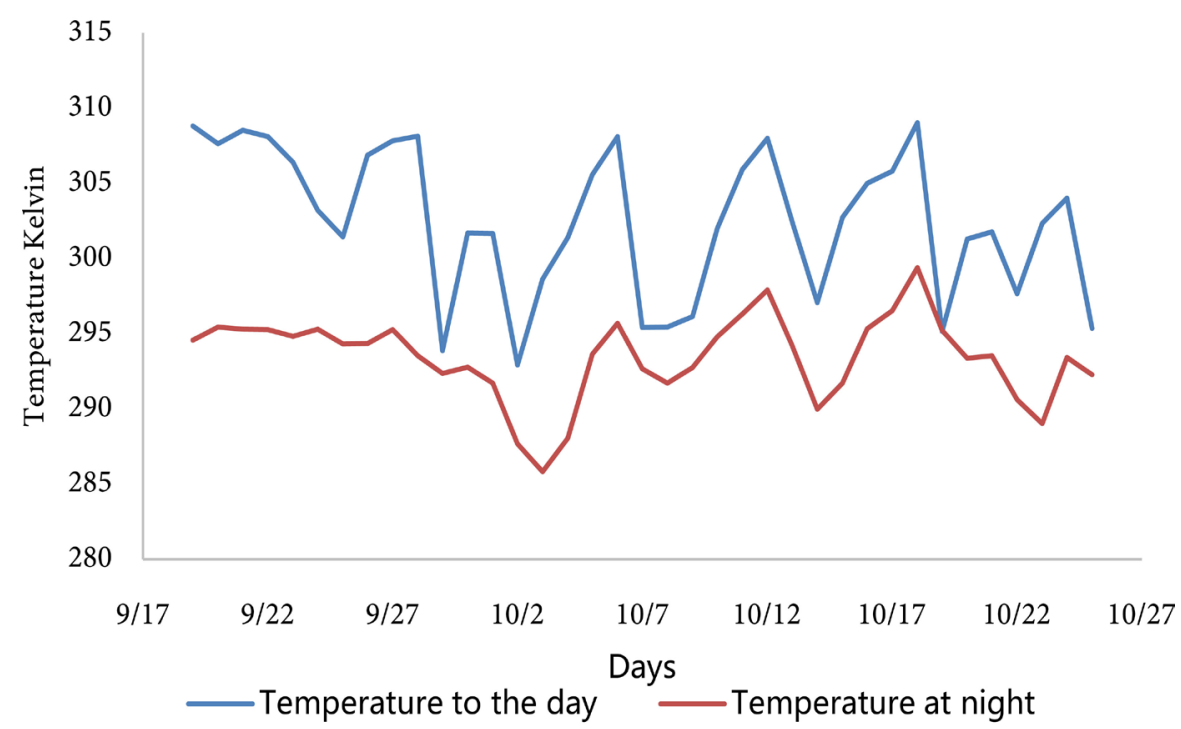

Figure 1. Temperature day and night in the year 2017 inside the greenhouse in the municipality of Marechal Cândido Rondon-PR. 
solubility technique established by the International Society of Humic Substances [15] and adapted by Benites et al. [16]. The second factor was the presence or absence of bacteria diazotrophic $A$. brasilense, obtained by commercial product the basis of strains AbV5 and AbV6, containing $2.0 \times 10^{8}$ colony forming units per $\mathrm{ml}$.

The seedlings production was carried out in trays of expanded polystyrene with dimensions of $0.34 \times 0.68 \times 0.06 \mathrm{~m}$ of width, length and height, respectively. Each tray has 200 cells with a volume of $40 \mathrm{~cm}^{3}$ and is used to fill commercial substrate with the composition based on pines bark, peat, coal and vermiculite. These were kept in greenhouse, with arched ceiling, coated with low density polyethylene film $(150 \mu$ thick $)$ and protected sides with white screen of $40 \%$ shading.

The implementation of the experiment started on 09/20/2017 and lasted 30 days. The lettuce cultivar employed was Grand Rapids, curly type, and at the time of sowing a seed was used in each cell of the tray. The inoculation with the humic acid occurred by applying it directly on the seeds, inside plastic bags, with subsequent vigorous stirring for two minutes for a homogeneous distribution of the product on the seeds. The dose of $5 \mathrm{ml}$ of the commercial product was used for inoculation with diazotrophic bacteria, also inside plastic bags, with subsequent vigorous stirring for two minutes for a homogeneous distribution of the product in the seeds. The seedlings were submitted to manual irrigation with irrigators, being carried out in three daily applications, according to the need of the seedlings.

For the germination test was performed in four replicates of 40 seeds per treatment. The emergence was monitored daily until 15 days after sowing (DAS) to determine the emergency rate (ER) [17], mean emergence time (MET) [17], emergence speed index (ESI) [18] and mean speed of emergency (MSE) [17].

$$
E R(\%)=(N / A) \times 100
$$

where: $E R$ is the emergency rate; $N$ is the number of emerged seeds; and $A$ is the total number of seeds placed to germinate.

$$
M E T=\frac{\sum n_{t} \times t_{i}}{\sum n_{\text {total }}}(\text { days })
$$

where: $M E T$ refers to the mean time of emergency in days; $n_{t}$ is the number of seeds emerged in a time interval; $t_{i}$ is the time interval; $n_{\text {total }}$ is the total number of emerged seeds.

$$
E S I=\left(E_{1} / N_{1}\right)+\left(E_{2} / N_{2}\right)+\cdots+\left(E_{n} / N_{n}\right)
$$

where: $E S I=$ emergency speed index. $E_{1}, E_{2}, E_{n}=$ number of normal seedlings computed in the first count, the second count and the last count. $N_{1}, N_{2}, N_{n}=$ number of days of sowing to the first, second and last count.

$$
M S E=1 / t \text { (seeds/day) }
$$

where: $M S E=$ mean speed of emergency; $t$ is the time interval. 
The plants were evaluated at the biometric level at 30 days after sowing (DAS), and 10 seedlings of each treatment were analyzed to compose the mean per plots, which were evaluated the number of leaves completely expanded (NL); height of plants $(\mathrm{H})$, using graduated ruler and measuring from the vegetable neck until the insertion of the last leaf; stem diameter (SD), using a digital caliper; length of the main root (LR), measured with a graduated ruler, from the insertion of the root at the base of the cervix to the root apex; dry shoot mass (DSM); root dry mass (RDM); and total dry mass (TDM). To obtain the dry mass the seedlings were separated in the different parts stored in identified paper bags and put to dry in a forced circulation air oven at $333.15 \mathrm{~K}$ until reaching constant mass, being in then weighed on a precision scale $(0.01 \mathrm{~g})$; and the Dickson quality index (IQD), according to the methodology used by Dickson et al. [19].

The data obtained between the treatments were submitted to analysis of variance (ANOVA) and the means compared by the Tukey test $(\mathrm{P} \leq 0.05)$, using the statistical program SISVAR 5.3 [20].

\section{Results and Discussion}

For the variables ER, MET, ESI, MSE, CR and $\mathrm{H}$ there were no significant differences by variance analysis for factors doses of humic acids and the absence or presence of diazotrophic bacteria, in addition to the combined factors (Table 1).

It can be observed in Table 1 the significant absence for characteristics of ER, MET, ESI and MSE, where the dilution of humic acid and the presence or absence of $A$. brasilense caused interference in the germination and emergence of lettuce. Cotrim et al. [10] found that inoculation of substances, such as humic acid, and/or, A. brasilense, in the early stages of germination and emergence of seeds tend not confer differences in these variables, since these phases, the

Table 1. Emergency rate (ER), mean emergence time (MET), emergence speed index (ESI), mean speed of emergency (MSE), root length (LR) and plant height (H), of seedlings of lettuce submitted to humic acid dilutions and with and without inoculation of diazotrophic bacteria.

\begin{tabular}{ccccccc}
\hline Dilutions & ER $(\%)$ & MET (Dias) & ESI & MSE & LR $(\mathrm{cm})$ & $\mathrm{H}(\mathrm{cm})$ \\
\hline 0 & $86.25 \pm 10.77$ & $6.10 \pm 1.71$ & $0.18 \pm 0.048$ & $6.67 \pm 2.23$ & $10.03 \pm 0.63$ & $3.74 \pm 0.45$ \\
25 & $78.44 \pm 13.49$ & $6.55 \pm 2.65$ & $0.17 \pm 0.054$ & $6.06 \pm 2.49$ & $10.04 \pm 0.32$ & $3.85 \pm 0.29$ \\
50 & $91.88 \pm 12.58$ & $5.09 \pm 1.06$ & $0.20 \pm 0.038$ & $8.10 \pm 1.87$ & $10.04 \pm 0.75$ & $3.58 \pm 0.14$ \\
75 & $85.00 \pm 13.02$ & $5.98 \pm 1.97$ & $0.18 \pm 0.056$ & $6.89 \pm 2.59$ & $10.35 \pm 0.94$ & $3.98 \pm 0.17$ \\
100 & $87.50 \pm 5.98$ & $5.21 \pm 0.91$ & $0.20 \pm 0.030$ & $7.39 \pm 1.06$ & $10.58 \pm 0.64$ & $3.84 \pm 0.30$ \\
With inoculation & $85.00 \pm 10.51$ & $5.51 \pm 1.26$ & $0.19 \pm 0.039$ & $7.06 \pm 1.90$ & $10.22 \pm 0.68$ & $3.80 \pm 0.38$ \\
No inoculation & $86.63 \pm 13.11$ & $6.06 \pm 2.17$ & $0.18 \pm 0.051$ & $6.99 \pm 2.39$ & $10.19 \pm 0.70$ & $3.79 \pm 0.22$ \\
CV (\%) & 11.28 & 24.95 & 20.26 & 23.13 & 6.77 & 8.16 \\
\hline
\end{tabular}

${ }^{*}$ Results not significant for analysis of variance at the $5 \%$ error probability level for dilutions, inoculation and interaction between factors and without not significant adjustments for regression analysis. 
embryonic axis depends on the accumulated resources throughout the process of seed maturation.

The results found, corroborate with those found by Venâncio et al. [21] that did not identify significant differences in the variables related to germination and emergence for pepper seeds, except in the ESI under some dosages of humic acids tested. These results of ER corroborate with those obtained in some studies of germination of different crops, such as corn [12] and chili [21].

Catão et al. [22] observed that high temperatures (308.15 K) negatively influenced germination and emergence in the Grand Rapids lettuce cultivar, used in this study. The authors attributed this influence to the lower activity of the enzyme $\beta$-mannanase in thermosensitive cultivars, since this enzyme promotes the weakening of the endosperm cell walls of the germinated seeds when submitted to high temperatures. These authors also verified a lower amount of HSP (Heat Shock Protein) proteins under the conditions of high temperatures in the thermosensitive cultivars, suggesting that the lower amount of this tolerant protein to high temperatures also influences the germination and emergence process of lettuce seedlings. From these elements, it was suggested that, although no statistical differences were found for ER, MET, ESI and MSE, the temperature condition during the initial period of the experiment (Figure 1) may have influenced the results, corroborating the lack of significant differences among the treatments evaluated.

Regarding the characteristics of $\mathrm{LR}$ and $\mathrm{H}$, it can be observed that there was no difference between the dilutions of humic acid nor between the presence or absence of inoculation. In contrast, Santos et al. [23], evaluating the dilutions of humic acid and nitrogen in the production of seedlings of Lactuca sativa L., found significant effects. These divergences occur mainly due to the presence of nitrogen, which assists in the growth process of the evaluated characteristics and due to the essential that is this nutrient for the initial development of the seedlings.

For the dry matter of roots (RDM) and total dry matter (TDM), a significant interaction was found for both the absence and the presence of bacteria with dilutions of humic acids $(\mathrm{P} \leq 0.05)$, and for leaf dry matter (DSM) only obtained interaction in the absence of inoculation with the dilutions of humic acids (Figure 2). These results indicate that inoculated seedlings presented variable responses to the doses used.

It can be observed in Figure 2 that the inoculation for TDM and RDM showed cubic behavior, which was observed a peak point at a dilution of 50\% humic acid, leading to a decrease in their mass. For the absence of bacteria showed an increasing linear behavior with the increase of the dilutions of humic acid employed, causing an increase in total dry mass and root. According to Façanha et al. [24], the application of humic substances promotes an increase in root development due to its stimulating effect similar to plant hormones, highlighting the ability of humic acids to provide an increase in an enzyme that 
TDM

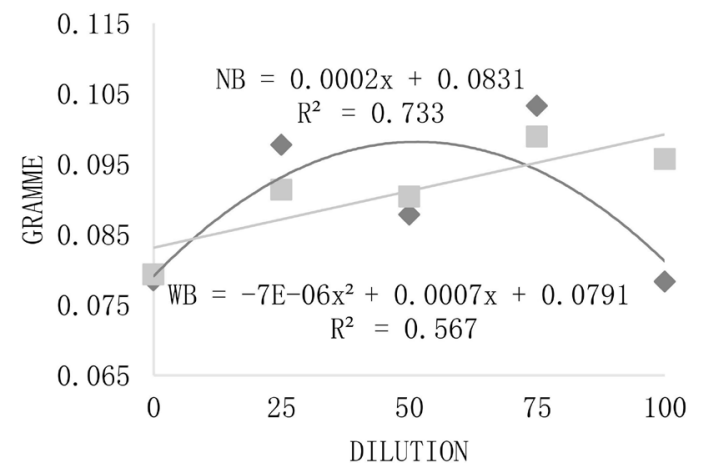

RDM

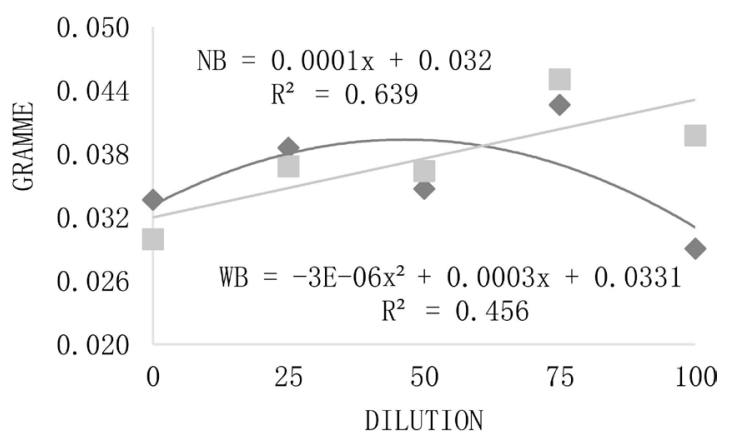

DSM

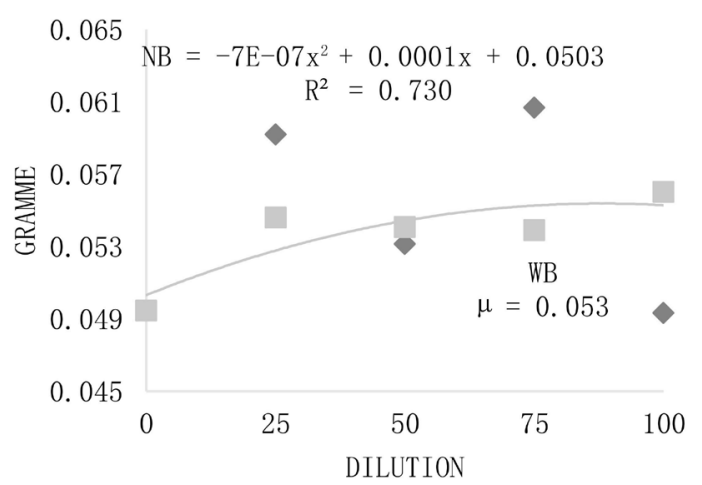

Note. NB - not bacteria; WB - with bacteria

Figure 2. Total dry matter (TDM), dry matter of root (RDM) and leaf dry matter (DSM) of lettuce seedlings submitted to dilutions of humic acid and, with and without inoculation of diazotrophic bacteria.

promotes root expansion.

Silva et al. [25], evaluating different sources of humic substances and different doses, verify significant effects of the doses on dry matter production of shoots and roots of lettuce plants. Meirelles et al. [4] found increases in several biometric parameters, productive and fresh matter of lettuce plants with the isolated use of humic acid and diazotrophic bacteria, mainly in the joint use of the substances reflected in higher yields.

For the variables number of leaves (NL), stem diameter (SD) and Dickson quality index (IQD) were not observed, nor was there any difference between inoculation and non-inoculation of bacteria, presenting only significant differences $(P \leq 0.05)$ for the dilutions of humic acids (Figure 3 ).

In relation to $\mathrm{NL}$, a gradual increase occurred, starting from the absence of humic acids, $0 \%$ (mean 4.8 leaves per plant), with the increase in dilution up to around $65 \%$ (means of 5.2 leaves per plant). From this point, the number of leaves reduced abruptly, especially after the dilution of $75 \%$ of humic acids, until reaching maximum dilution, where the number of leaves observed was, on mean, 4.6 leaves per plant, where the cubic adjustment was significant and the worst results are observed. Similar results were observed in other studies with 


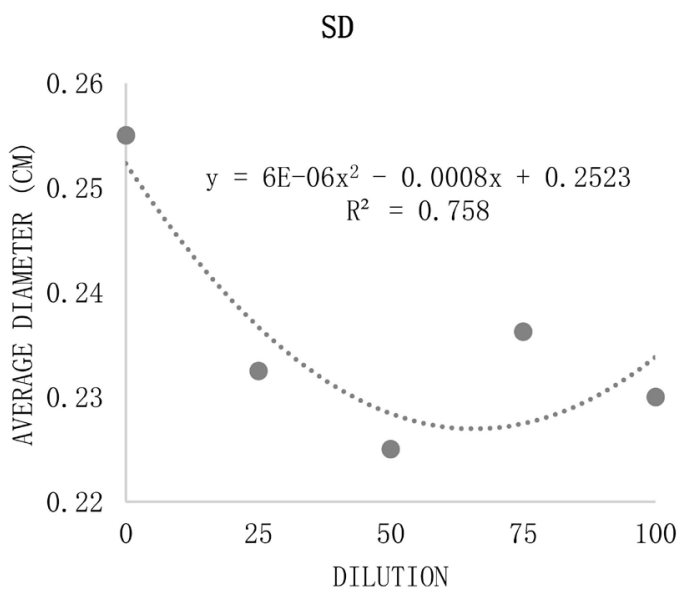

NL

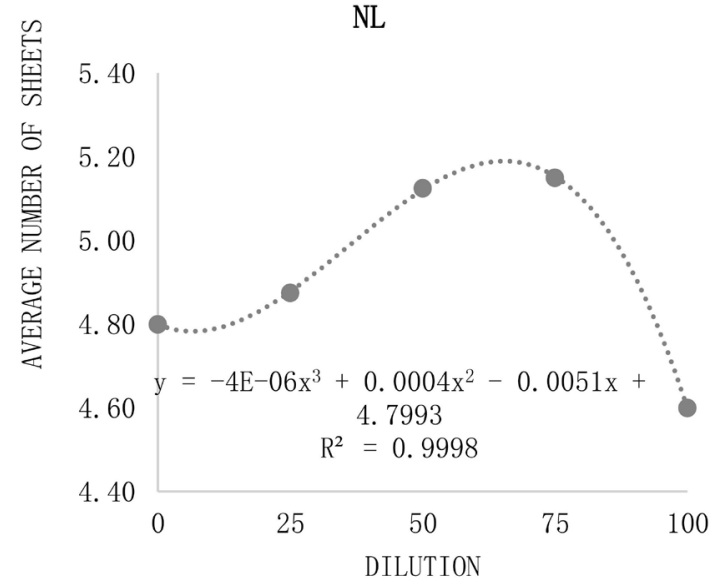

IQD

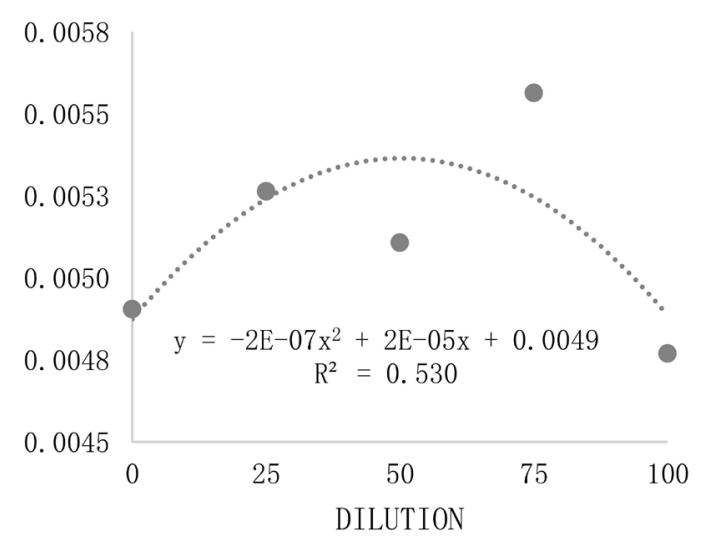

Figure 3. Number of leaves (NL), stem diameter (SD) and Dickson quality index (IQD) of lettuce seedlings submitted to dilutions of humic acid and with and without inoculation of diazotrophic bacteria.

the use of humic substances in other crops, such as cucumber [26], tomato [27] and wheat [10]. Borcioni et al. [1] observed higher lettuce NL with the application of these humic substances up to the dose of $4 \mathrm{ml} \mathrm{L}^{-1}$, from this concentration, the number of leaves reduced.

For the SD, significant differences were found for inoculation with the bacterium. The inoculated plants presented a SD average of $0.24 \mathrm{~cm}$ and those not inoculated $0.22 \mathrm{~cm}$. Differences were also observed for the dilutions of humic acids, being detected significance for the quadratic adjustment, with coefficient of determination explaining $76 \%$ of the observed data. For this variable under the conditions of the study, a reduction in stem diameter averages occurred with the increase of the dilution of humic acids up to approximately $66 \%$ and, from this dilution, there was an increase in the means of this variable. Besides the presence of bacteria influenced to a larger diameter when compared to non-inoculated plants.

Cavalcante et al. [6] observed reduction in stem diameter in passion fruit seedlings with applications of humic substances. Nomura et al. [28] found a decrease in banana SD in winter when they tested two commercial biofertilizers. Some authors argue that seedlings with larger diameter tend to favor the survival 
rate of these seedlings after transplanting [28] [29] [30]. This tendency is due to the fact that this variable is strongly influenced by the number and vigor of the root system, which allow plants more tolerant to biotic stresses, thus favoring initial development as well as increasing production [28].

In relation to the IQD, significant differences were found only for the dilutions of humic acid, which the best fit was the quadratic one due to the different dilutions tested and with a correlation coefficient explaining $53 \%$ of the observed data. The behavior of the obtained curve pointed to increase in IQD up to approximately $50 \%$ of humic acid dilution, with IQD of 0.0054 , with decrease in the highest dilutions. The IQD is obtained by the ratio between several variables, TDM, H, SD, DSM and RDM, and from its result it is possible to infer about the quality by means of its equilibrium, thus, the higher the IQD value obtained, the higher the quality of seedlings produced. Santos et al. [30] observed improvement in the quality of lettuce cv. "Verônica" with the application of humic acids, obtaining a IQD up to 0.0123 .

The increase in the dilution of humic acid negatively affected the SD, which has negative consequences for the IQD of the lettuce seedlings. However, due to the fact that this index takes into account several parameters of seedling growth [29], it was still possible to verify IQD higher than those observed in other studies involving this index in lettuce seedlings [31] [32].

In general, the results presented here indicate that the seedlings produced were of good quality. It is possible to emphasize that the use of humic acid up to the $50 \%$ dilution applied in seed was beneficial for the quality of the seedlings produced.

\section{Conclusions}

The main conclusions are:

The association of diazotrophic bacteria and humic acids did not influence the emergency rate, mean emergence time, mean speed of emergency, emergence speed index, plant height, and root length of lettuce seedlings.

The dilutions of humic acids, regardless of inoculation with bacteria diazotrophic favored the development of the number of leaves, stem diameter and Dickson quality index.

Inoculation of lettuce seeds diazotrophic bacteria associated with the addition of humic acids favored the development of the dry mass of root and total dry matter.

\section{Acknowledgements}

We want to give thanks to the Coordination for the Improvement of Higher Education Personnel (CAPES) by the scholarship of the master's degree and resources for conducting the research.

\section{References}

[1] Borcioni, E., Mógor, Á.F. and Pinto, F. (2016) Aplicação de ácido fúlvico em mudas 
influenciando o crescimento radicular e produtividade de alface americana. Revista de Ciência Agronômica, 47, 509-515. https://doi.org/10.5935/1806-6690.20160061

[2] Coutinho, P.W.R., Cadorin, D.A., Vanelli, J. and Dalastra, G.M. (2017) Produção de mudas de alface em diferentes bandejas e substratos. Revista Géfyra, 1, 1-10.

[3] Echer, M.M., Guimarães, V.F., Aranda, A.N., Bortolazzo, E.D. and Braga, J.S. (2007) Avaliação de mudas de beterraba em função do substrato e do tipo de bandeja. Ciências Agrárias, Londrina, 28, 45-50. https://doi.org/10.5433/1679-0359.2007v28n1p45

[4] Meirelles, A.F.M., Baldotto, M.A. and Baldotto, L.E.B. (2017) Produtividade de alface (Lactuca sativa L.) em resposta à aplicação de ácidos húmicos e bactérias diazotróficas, em condições de campo. Revista Ceres, Viçosa, 64, 553-556. https://doi.org/10.1590/0034-737x201764050014

[5] Kozusny-Andreani, D.I. and Andreani Junior, R. (2014) Colonização rizosférica e promoção do crescimento por rizóbios em mudas de alface. Nucleus, 11, 443-452. https://doi.org/10.3738/1982.2278.1108

[6] Cavalcante, I.H.L., Silva-Matos, R.R.S., Albano, F.G., Silva Júnior, G.B., Silva, A.M. and Costa, L.S. (2013) Foliar Spray of Humic Substances on Seedling Production of Yellow Passion Fruit. Journal of Food, Agriculture \& Environment, 11, 301-304.

[7] Canellas, L.P., Silva, S.F., Olk, D.C. and Olivares, F.L. (2015) Foliar Application of Plant Growth-Promoting Bacteria and Humic Acid Increase Maize Yields. Journal of Food, Agriculture \& Environment, 13, 146-153.

[8] Canellas, L.P., Spaccini, R., Piccolo, A., Bobbss, L.B., Okorokova-Façanha, A.L., Santos, G.A., Olivares, F.L. and Façanha, A.R. (2009) Relationships between Chemical Characteristics and Root Growth Promotion of Humic Acids Isolated from Brazilian Oxisols. Soil Science, 174, 611-620.

https://doi.org/10.1097/SS.0b013e3181bf1e03

[9] Jordão, L.T., Lima, F.F., Lima, R.S., Moretti, P.A.E., Pereira, H.V., Muniz, A.S. and Oliveira, M.C.N. (2010) Teor relativo de clorofila em folhas de milho inoculado com Azospirillum braziliense sob diferentes doses de nitrogênio e manejo com braquiária. In: FERTBIO, SBCS, Guarapari.

[10] Cotrim, M.F., Alvarez, R.C.F. and Seron, A.C.C. (2016) Qualidade fisiológica de sementes de trigo em resposta a aplicação de Azospirillum brasilense e ácido húmico. Brazilian Journal of Biosystems Engineering, Tupã, 10, 249-357.

[11] Olivares, F.L., Aguiar, N.O., Rosa, R.C.C. and Canellas, L.P. (2015) Substrate Biofortification in Combination with Foliar Sprays of Plant Growth Promoting Bacteria and Humic Substances Boosts Production of Organic Tomatoes. Scientia Horticulturae, 183, 100-108. https://doi.org/10.1016/j.scienta.2014.11.012

[12] Conceição, P.M., Vieira, H.D.V., Canellas, L.P., Olivares, F.L. and Conceição, P.S. (2009) Efeito dos ácidos húmicos na inoculação de bactérias diazotróficas endofíticas em sementes de milho. Ciência Rural, Santa Maria, 39, 1880-1883. https://doi.org/10.1590/S0103-84782009005000137

[13] Alvares, C.A., Stape, J.L., Sentelhas, P.C., de Moraes Gonçalves, J.L. and Sparovek, G. (2014) Köppen's Climate Classification Map for Brazil. Meteorologische Zeitschrift, 22, 711-728. https://doi.org/10.1127/0941-2948/2013/0507

[14] Caviglione, J.H., Kiihl, L.R.B., Caramori, P.H. and Oliveira, D. (2000) Cartas climáticas do Paraná. IAPAR, Londrina.

[15] Swift, R.S. (1996) Organic Matter Characterization. In: Sparks, D.L., Page, A.L., Helmke, P.A., Loeppert, R.H., Soltanpour, P.N., Tabatabai, M.A., Johnston, C.T. and Sumner, M.E., Eds., Methods of Soil Analysis: Chemical Methods, SSSA. Book 
Series 5, Soil Science Society American, Madison, 1011-1020.

[16] Benites, V.M., Madari, B. and de Machado, P.L.O.A. (2003) Extração e fracionamento quantitativo de substâncias húmicas do solo: Um procedimento simplificado e de baixo custo. Embrapa Solos, Rio de Janeiro, 7 p.

[17] Labouriau, L.G. (1983) A germinação de sementes. OEA, Washington, 174 p.

[18] Maguire, J.D. (1962) Speed of Germination Aid in Selection and Evaluation for Seeding Emergence 440 and Vigor. Crop Science, 2, 76-177.

https://doi.org/10.2135/cropsci1962.0011183X000200020033x

[19] Dickson, A., Leaf, A.L. and Hosner, J.F. (1960) Quality Appraisal of White Spruce and White Pine Seedling Stock in Nurseries. Forestry Chronicle, 36, 10-13. https://doi.org/10.5558/tfc36010-1

[20] Ferreira, D.F. (2014) Sisvar: A Guide for Its Bootstrap Procedures in Multiple Comparisons. Ciência e Agrotecnologia, Lavras, 38, 109-112.

[21] Venâncio, L.P., Lopes, J.C., Thomazini, A. and Freitas, A.R. (2012) Efeito do condicionador de solo Fertium na germinação e no desenvolvimento de plântulas de pimentão. Nucleus, 9, 241-246. https://doi.org/10.3738/1982.2278.791

[22] Catão, H.C.R.M., Gomes, L.A.A., Santos, H.O., Guimarães, R.M., Fonseca, P.H.F. and Caixeta, F. (2014) Aspectos fisiológicos e bioquímicos da germinação de sementes de alface em diferentes temperaturas. Pesquisa Agropecuária Brasileira, 49, 316-322. https://doi.org/10.1590/S0100-204X2014000400010

[23] Santos Acm, R.R., Andrade, C.A.O., Freitas, G.A., Silva, D.B., Silva, R.J. and Silva, R.R. (2014) Concentrações de ácido húmico e nitrogênio na produção de mudas de Lactuca sativa. Amazon Soil. In: I Encontro de CIÊNcia do Solo da Amazônia Oriental, Anais, Sociedade Brasileira de Ciência do Solo, Guarupi, 73-82.

[24] Façanha, A.R., Façanha, A.L.O., Olivares, F.L., Guridi, F., Santos, G.D.A., Velloso, A.C.X. and Canellas, L.P. (2002) Bioatividade de ácidos húmicos: Efeito sobre o desenvolvimento radicular e sobre a bomba de prótons da membrana plasmática. Pesquisa Agropecuária Brasileira, Brasília, 37, 1301-1310. https://doi.org/10.1590/S0100-204X2002000900014

[25] da Silva, R.M., Jablonski, A., Morselli, T.B.G.A., Garcia, S.S. and Kroth, P.L. (2000) Produção de alface cultivado em solução nutritiva completa com adição de substâncias húmicas extraídas de sete carvões minerais. Revista Científica Rural, 5, 13-23.

[26] Rauthan, B.S. and Schnitzer, M. (1981) Effects of a Soil Fulvic Acid on the Growth and Nutrient Content of Cucumber (Cucumis sativus) Plants. Plant and Soil, 63, 491-495. https://doi.org/10.1007/BF02370049

[27] Türkmen, O., Dursun, A., Turan, M. and Erdinç, C. (2004) Calcium and Humic Acid Affect Seed Germination, Growth, and Nutrient Content of Tomato (Lycopersicon esculentum L.) Seedlings under Saline Soil Conditions. Acta Agriculturae Scandinavica, Section B-Soil \& Plant Science, 54, 168-174.

[28] Nomura, E.S., Damatto Junior, E.R., Fuzitani, E.J., Saes, L.A. and Jensen, E. (2012) Aclimatação de mudas micropropagadas de bananeira "Grand Naine" com aplicação de biofertilizante em duas estações do ano. Revista Ceres, Viçosa, 59, 518-529.

[29] Costa, E., Durante, L.G.Y., Nagel, P.L., Ferreira, C.R. and Santos, A. (2011) Qualidade de mudas de berinjela submetida a diferentes métodos de produção. Revista Ciência Agronômica, Fortaleza, 42, 1017-1025. https://doi.org/10.1590/S1806-66902011000400026 
[30] Santos, A.C.M., Rodrigues, L.U., Andrade, C.A.O., Carneiro, J.S.S. and Silva, R.R. (2018) Ácidos húmicos e nitrogênio na produção de mudas de alface. Pesquisa Aplicada \& Agrotecnologia, Guarapuava, 11, 69-77.

[31] Freitas, G.A., Silva, R.R., Barros, H.B., Vaz-de-Melo, A. and Abrahão, W.A.P. (2013) Produção de mudas de alface em função de diferentes combinações de substratos. Revista Ciência Agronômica, Fortaleza, 44, 159-166. https://doi.org/10.1590/S1806-66902013000100020

[32] Simões, A.C., Alves, G.K.E.B., Ferreira, R.L.F. and Araújo Neto, S.E. (2015) Qualidade da muda e produtividade de alface orgânica com condicionadores de substrato. Horticultura Brasileira, 33, 521-526.

https://doi.org/10.1590/S0102-053620150000400019 